\title{
A Contrastive Analysis of the Use of Prepositions in German and Indonesian
}

\author{
Hasmawati', Mantasiah R. ${ }^{2}$, Yusri ${ }^{3}$ \\ 1,2 Foreign Language Education, Universitas Negeri Makassar, Makassar, Indonesia \\ ${ }^{3}$ English Literature, Universitas Fajar, Makassar, Indonesia \\ Email: hasmawati@unm.ac.id'
}

Submitted: 02/01/2020

Revised: 15/01/2020

Accepted: $18 / 02 / 2020$

E-ISSN : $2579-4574$

P-ISSN : 2549-7359

\begin{abstract}
This study aims to describe the implication of contrastive analysis in the mastery of prepositions in German and Indonesian by identifying the similarities and differences in terms of morphology, semantics and syntax. This study employed library research technique to collect data related to the use of prepositions in German and Indonesian. The results of analysis found that there are similarities and differences in using the prepositions in German and Indonesian. Based on the word structure or the morphological aspect, prepositions in German and Indonesian are divided into two: primary/pure/basic prepositions and secondary/derivative prepositions. In German and Indonesian, primary prepositions are single words, which are called prepositions with one case in German (Präpositionen mit festem Kasus). From the semantic point of view, German prepositions are divided into four types: 1) prepositions indicating locative relationship, 2) temporal relationship, 3) modal relationship, and 4) cause-effect relationship. In Indonesian, however, prepositions are divided into several types: 1) prepositions indicating location, 2) movement, 3) agents, 4) tools, 5) comparison, 6) a thing or problem, 8) effects, and 9) prepositions indicating purpose. In general, those prepositions have similar meanings with prepositions in German, but the formations are different because prepositions in German use one of the cases: accusative, dative or genitive.
\end{abstract}

Keywords: Contrastive, Preposition, German, Indonesian

https://ojs.unm.ac.id/eralingua

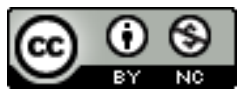

This work is licensed under a Creative Commons Attribution-NonCommercial 4.0 International License 


\section{INTRODUCTION}

German is classified into the 15th Germanic language, a family within the Indogermanic language group. German is the most widely spoken native language in the European Union (EU) and the tenth most spoken language in the world. German is the native language to approximately 120 million people and ranked second as a foreign language in Europe. Today around 17 million people worldwide learn German in institutions or schools. The German Ministry of Foreign Affairs promotes the teaching of German in foreign countries through an intermediary organization, the Goethe Institut. This institute offers German courses in 127 cities within 80 countries. Deutscher Akademischer Austauschdienst (DAAD) has mandated 440 lecturers to teach in universities in 102 countries. The central agency for overseas universities ( $\mathrm{ZfA}$ ) manages 135 German schools and about 1,900 German teachers teach abroad. An effort to strengthen the position of German as a foreign language abroad is the establishment of The Future School by Ministry of Foreign Affairs, which aims to create a network with partner schools.

The above explanation highlights the importance of conducting research on German, especially for developed countries such as Indonesia. For a past few years, the bilateral relations between Indonesia and German have become more notable in the fields of research and technology, such as: marine science and technology, energy, aeronautics, space, geology, social sciences and other non-exact sciences. A number of Indonesian universities in Indonesia have collaborated with German universities. The results of the collaboration significantly benefit the development of Indonesia that later provides opportunities for Indonesian students who are eager to study abroad. Therefore, the improvement of German language skills is vital.

There are some previous studies conducting German language learning for Indonesian learners (Wijayanti \& Ayub, 2018; Usman, Saud, \& Achmad, 2018; Mantasiah et al., 2019; Saud \& Weda, 2019). The studies show that there are some factors influencing German language learning process, and there are some alternative methods which can be implemented to support German language learning. One of them is by conducting contrastive analysis between German and Indonesian language. By contrasting the languages, students are easier to understand in learning the language (Khansir \& Pakdel, 2019; Mejias, 2019; Aljohani, 2019; Xiao \& Widodo, 2019).

German and Indonesian are not cognate languages which cause many differences between the two, especially in morphological, syntactical, semantic and grammatical aspects. German's sentence structure is subject - verb (predicate) - object (SVO). However, in subordinate sentences, the structure is subject - object - verb (SOV). Moreover, the use of prepositions is always influenced by the verbs that follow since prepositions determine the "case" of the noun article, for example nominative, accusative, dative or genitive case. These differences will seem to be more interesting if German is compared with Indonesian through a contrastive analysis approach. More importantly, the words' semantic roles can be observed through cross-cultural studies.

Even though Indonesian and German belong to two different typology language groups, these two languages have similarities in morphological, semantic or syntactical aspects. Every language has not only its own characteristics or patterns, but also the nature of universality. Non-cognate language can be studied using contrastive or comparative analysis, which is the most appropriate approach to help students understand the lessons better since the patterns of two languages are presented side by 
side. Despite the emergence of more innovative and modern learning methods, the contrastive analysis approach has effective techniques to foreign language learning, as evidenced by the number of studies conducted on the contrastive uses of prepositions of German and Indonesian. The current study employed a structural linguistic theory in order to obtain more detailed description.

\section{RESEARCH METHOD}

This descriptive qualitative study aims to describe in depth the uses of German and Indonesian prepositions from a contrastive standpoint. The data sources of this study were scientific books and journals which were selectively relevant with the aim of the study, especially about the prepositions and grammar of German and Indonesian; German-Indonesian Dictionary by Adolf Heuken (2007), Langenscheidts Grobwörterbuch by Götz et al. (2011); and Great Dictionary of the Indonesian Language of the Language Center by Ministry of Education and Culture (2008). Data were collected using the library research technique in order to obtain both primary and secondary data which were in the form of theories of the use of prepositions in German and Indonesian.

Data were identified based on the forms or patterns of the use of prepositions. Subsequently, data were classified in accordance with the elements that accompanied them. As a result, similar prepositions were easily categorized. In addition, the results of analysis of German and Indonesian were contrasted in order to observe the similarities and differences. For data analysis, the contrastive analysis technique with the adaptation of the theory by Lado (1971) was applied:

First: Place the best structural description of the languages involved. The descriptions of both languages should contain forms, meanings, and distribution of the structure. The form, meaning and distribution must be explained in detail before continuing further analysis.

Second: Summarize all structures in an overview.

Third: $\quad$ Make structural comparison of the two languages in a pattern-by-pattern manner.

Fourth: Predict the difficulties that might occur.

\section{RESULT AND DISCUSSION}

Prepositions are actively used in communication. In regards to the definition of preposition, Reimann (2002) states that "Präpositionen stellen eine Beziehung zwischen Satzelementen her. Sie können stehen vor einem Nomen, Pronomen, Adjektiv oder Adverb", meaning that preposition connects the elements of a sentence with their locations before nouns, pronouns, adjectives and adverbs. Prepositions can also be placed before and after nouns/pronouns, such as entlang, gegenüber and nach in German language.

In relation to the above explanation, Helbig \& Buscha (2001) divided prepositions into four groups on the basis of locations, namely:

(1) Prepositions before nouns, pronouns or adverbs (Prästellung);

(2) Prepositions before or after nouns, pronouns or adverbs (Prä- und Poststellung);

(3) Prepositions after nouns, pronouns or adverbs (Poststellung); and 
(4) Prepositions before and after nouns, pronouns or adverbs (Circumstellung), meaning that the prepositions consist of two words; one is placed before and the other is placed after nouns, pronouns or adverbs.

It can be concluded that preposition is a word used to link the elements of a sentence and placed before, after, either before or after, as well as one before and the other one after nouns, pronouns or adverbs.

\section{Similarities and Differences of Prepositions between German and Indonesian}

Based on their structures, the prepositions of German and Indonesian are categorized into two; primary, basic or pure prepositions and secondary or derivative prepositions.

\section{Primary Prepositions of German and Indonesian}

Primary prepositions are prepositions that are pure, not derived from other types of words or resulted from the combination of words of different types. In German and Indonesian, primary prepositions are single words prepositions, which are the same with prepositions in German that have one case (Präpositionen mit festem Kasus or prepositions followed by one case). Single word prepositions in German consist of:

a) Preposition followed by accusative cases: durch, für, gegen, ohne, um, entlang. For examples:

Das Kind läuft um einen Tisch.

'The child runs around a table.'

b) prepositions followed by dative cases: aus, außer, bei, gegenüber, mit, nach, seit, von, zu). For examples:

Maria wohnt bei ihrer Tante.

'Maria lives with her aunt.'

c) prepositions followed by accusative or dative cases: an, auf, hinter, in, neben, unter, über, vor, zwischen). For examples:

- Erika und Mirna sitzen am Tisch. dative

'Erika and Mirna sit near the table.'

- Erika und Mirna setzen sich an den Tisch. Accusative

'We take a seat near the table.'

d) prepositions followed by genitive cases: (an) statt, trotz, auberhalb, innerhalb, and während.

In Indonesian, single word prepositions consist of two types:

a) Basic words consisting of one morpheme: di (in/at), ke (to), dari (from), untuk (for).

For example:

Ibu membeli motor untuk Ari.

'Mother buys a motorbike for Ari.'

b) Affixed words, which refer to prepositions that receive affixes in the basic forms that belong to verbs, adjectives or nouns. Affixation in this formation can be resulted from additions of prefixes, suffixes or the combination of the two. For examples:

- Prefixed prepositions: bersama 'with' and menjelang 'toward' and menuju 'toward' Ayah pergi bersama ibu. 
'My father goes with my mother.'

- Suffixed preposition: bagaikan 'like'

Gadis itu cantik bagaikan bidadari.

'The girl is beautiful like an angel.'

- Prefixed and suffixed prepositions: melalui 'through' and mengenai 'about'

Saya membayar tagihan PLN melalui mobile banking.

'I pay the electric bill through mobile banking.'

The preposition bersama 'with' in the example above is a prefixed preposition, which refers to the combination of the base sama and prefix -ber-. Similarly, the preposition bagaikan 'like' in the above example is the combination of the base bagai and suffix -kan.

\section{Secondary Prepositions in German and Indonesian}

In addition to primary prepositions, both German and Indonesians have secondary prepositions, which are derived from primary prepositions or are not original forms because they receive additions from other elements. The examples of secondary or derivative prepositions are anfangs 'start', inmitten 'in the middle' and zuliebe 'for' as well as nouns that receive suffix $-s$ or lich, such as anfangs 'at the beginning', gelegentlich 'sometimes', etc. Helbig \& Buscha (2001) categorizes secondary prepositions into:

a) Prepositions of which the word structure is the same with other words.

These prepositions have the same characteristics or forms as other types of words, but they are distinguishable from other types of words based on their structure in sentences. The examples of secondary prepositions are kraft, lang ausgenommen, nahe, dank, laut, entsprechend, etc.

b) Prepositions derived from other types of words (characterized with suffix -s or -lich) These prepositions are derived from other types of words, which are characterized with suffix -s or -lich, for examples längs, betreffs, , mangels, mittels, namens, seitens, zwecks, dies-, abzüglich, einschließlich, hinsichtlich, , etc.

c) Compound words consisting of preposition + noun without an article

These prepositions are derived from the combination of preposition and noun without article. The examples of prepositions of this kind are aufgrund, anhand, anstatt/anstelle, inmitten, mithilfe, infolge, zufolge, zugunsten. Some compound words are written in word groups: mit Hilfe, an Stelle, von Seiten, auf Grund, zugunsten.

d) Word groups consisting of preposition + definite noun or without article these prepositions are the combination of a preposition and a definite noun or without article. The examples of prepositions of this type include auf der Basis, auf Kosten, auf dem Wege, aus Anlass, aus Richtung, aus der Sicht, in Anbetracht, im Ergebnis, im Interesse, mit Ausnahme, mit dem Ziel, unter Beachtung, unter Einfluss, zum Nachteil, zum Preis.

Most secondary prepositions in German are followed by genitive cases. Some are followed by dative cases (dank, entsprechend, laut, nahe, zufolge, zuliebe), and some others are followed by accusative cases (ausgenommen, lang). Different from German, Indonesian secondary prepositions or compound prepositions are divided into:

a) two-word prepositions, prepositions that consist of two words one after the other. For examples: dari pada 'instead', oleh karena 'because of', sampai ke 'until'. 
Kami berlari sampai ke tepi laut.

'We run off until the edge of the sea.

b) correlated prepositions, prepositions that consist of two elements used as a pair, but separated by another word or phrase. For examples: antara ... dengan... (between ... and ...), dari ... hingga ... (from ... until ...) and dari ... ke ... (from ... to ...).

Orang itu bekerja dari pagi hingga petang.

'The man works from morning until evening.'

c) Prepositions and locative nouns, prepositions that can be combined with two nouns if the first noun is locative. For examples: di atas meja 'on the table', ke dalam rumah 'into the house'.

\section{CONCLUSION}

Prepositions in German and Indonesian have similar and different uses. Based on the word structure, or morphology, prepositions in German and Indonesian are divided into two: primary, basic or pure prepositions and secondary or derivative prepositions. Primary prepositions are pure prepositions, which are not derived from other words or made by combining words. In German and Indonesian, primary prepositions include single-word prepositions, which are called prepositions with one case in German (Präpositionen mit festem Kasus). Semantically speaking, prepositions in German are divided into four types, 1) prepositions indicating spatial relationship: an, auf, aus, auBerhalb, bei, durch, entlang, hinter, in, nach, neben, über, unter, vor, zu; 2) prepositions indicating temporal relationship: $a b$, an, bis, in, seit, von, während; 3) prepositions indicating modal relationship: auf, aus, bei, in, unter; and 4) prepositions indicating causeeffect relationships: durch, mit, von, vor. On the other hand, prepositions in Indonesian are also categorized into: 1) prepositions indicating location: di 'at', pada 'at', dalam 'in', atas 'on', and antara 'between'; 2) prepositions indication movement from: dari 'from'; 3 ) prepositions indicating movement to: ke 'to', kepada 'to', akan 'for', and terhadap 'to'; 4) prepositions indicating agents: oleh 'by'; 5) prepositions indicating tools: dengan 'with' and berkat 'by'; 6) prepositions indicating comparison: daripada 'than'; 7) prepositions indicating a thing or problem: tentang and mengenai 'about'; 8) prepositions indicating effects: hingga and sampai 'until'; and 9) prepositions indicating purpose: untuk, buat, guna and bagi 'for', 'to'. In general, those prepositions have similar meanings with prepositions in German, but the formations are different because prepositions in German use one of the cases: accusative, dative or genitive.

\section{REFERENCES}

Aljohani, A. A. (2019). Contrastive Analysis: Difficulties Arabic Learners Face in Using English Language Tenses. Journal of Applied Linguistics and Language Research, 6(2), 146-156.

Departemen Pendidikan Indonesia (2008). Kamus Besar Bahasa Indonesia. Jakarta: Balai Pustaka

Götzt, Dieter; Haensch, Günther; Wellmann, Hans. (1997). Langescheidts Grobwörterbuch, Deutsch als Fremdsprache. Berlin, Langenscheidt.

Helbig, Gerhard \& Buscha, Joachim. (2001). Deutsche Grammatik : Ein Handbuch für den Ausländerunterricht. Leipzig, Berlin, München : Langenscheidt.Verlag Enzyklopädie.

Heuken, SJ A. (2007). Kamus Jerman- Indonesia. Jakarta: Gramedia PustakaUtama 
Khansir, A. A., \& Pakdel, F. (2019). Contrastive Analysis Hypothesis and Second Language Learning. Journal of ELT Research: The Academic Journal of Studies in English Language Teaching and Learning, 35-43.

Lado, Robert. (1971). Linguistics Across Cultures, The University of Michigan Press.

Mantasiah, R., Yusri, Y., Syaputra, A. F., Angreany, F., Hasmawati, H., \& Anwar, M. (2019, December). Assessing Mistake Potential in Writing German Passive Sentences (An Approach of Language Error Analysis). In Seminar Nasional LP2M UNM.

Mejías, J. M. (2019). A Contrastive Analysis of Lexical Availability in Spanish and English as a Second Language at Tertiary Level Francisco J. Álvarez-Gil. Journal of Foreign Language Teaching and Applied Linguistics, 51.

Reimann, Monika. (2002). Grundstufen-Grammatik : für Deutsch als Fremdsprache. Ismaning : Max Hueber Verlag.

Saud, S., \& Weda, S. (2019). A comparative Study Of English and German Syntactic Variation by Students at Higher Education: Evidence from Complex Predicates. The Asian EFL Journal, 21(2.2), 176-195.

Usman, M., Saud, S., \& Achmad, A. K. (2018). Learning Model Development Of TeamsGames-Tournaments (TGT) In Learning German Vocabulary (Wortschatz) For Senior High School Students In Makassar. International Journal of Language Education, 2(2), 105-112.

Wijayati, P. H., \& Ayub, A. F. M. (2018). “My lecturer's expressionless face kills me!” An evaluation of learning process of German language class in Indonesia. REiD (Research and Evaluation in Education), 4(2), 94-104.

Xiao, Q., \& Widodo, P. (2019). Contrastive Analysis Of Particles In Chinese And Indonesian Language. LITERA, 18(3). 